\title{
Activation of nuclear factor kappa B (NF- KB) by connective tissue growth factor (CCN2) is involved in sustaining the survival of primary rat hepatic stellate cells Runping Gao ${ }^{1,2}$ and David R Brigstock*1,2,3
}

Address: ${ }^{1}$ Center for Cell and Vascular Biology, Children's Research Institute, Columbus Ohio 43205 USA, ${ }^{2}$ Department of Surgery, The Ohio State University, Columbus, Ohio 43212 USA and ${ }^{3}$ Department of Molecular and Cellular Biochemistry, The Ohio State University, Columbus, Ohio 43212 USA

Email: Runping Gao - gao_runping@yahoo.com; David R Brigstock* - brigstod@ccri.net

* Corresponding author

Published: 22 November 2005

Cell Communication and Signaling 2005, 3:14 doi: I0.I I86/I478-8IIX-3-14

This article is available from: http://www.biosignaling.com/content/3/I/14

(c) 2005 Gao and Brigstock; licensee BioMed Central Ltd.

This is an Open Access article distributed under the terms of the Creative Commons Attribution License (http://creativecommons.org/licenses/by/2.0), which permits unrestricted use, distribution, and reproduction in any medium, provided the original work is properly cited.
Received: 29 August 2005

Accepted: 22 November 2005

\begin{abstract}
Background/Aims: Connective tissue growth factor (CCN2) is a matricellular protein that plays a role in hepatic stellate cell (HSC)-mediated fibrogenesis. The aim of this study was to investigate the regulation by CCN2 of cell survival pathways in primary HSC.

Methods: Primary HSC were obtained by in situ enzymatic perfusion of rat liver. NF- $\mathrm{KB}$ activation was assessed by immunoblotting for $1 \kappa B \alpha$ phosphorylation and degradation and by NF- $\kappa B$ p50 or p65 nuclear accumulation. NF-KB DNA-binding activity was determined by gel mobility shift assay while NF- $\kappa B$ response gene expression was evaluated using a luciferase reporter. Cell viability was assessed by Trypan blue staining or ATP luminescent assay while apoptosis was evaluated by caspase-3 activity.

Results: $\mathrm{CCN} 2$ induced IKB $\alpha$ phosphorylation and degradation as well as nuclear accumulation of NF- $\mathrm{KB}$. Activated NF- $\mathrm{KB}$ comprised three dimers, p65/p65, p65/p50 and p50/p50, that individually bound to DNA-binding sites and subsequently triggered transcriptional activity. This was confirmed by showing that $\mathrm{CCN} 2$ promoted activity of a NF-KB luciferase reporter. CCN2 promoted survival of serum-starved HSC and protected the cells from death induced by blocking the NF-KB signaling pathway using Bay-I I-7082, a specific inhibitor of IKB $\alpha$ phosphorylation.
\end{abstract}

Conclusion: CCN2 contributes to the survival of primary HSC through the NF-KB pathway.

\section{Introduction}

Hepatic stellate cells (HSC) are the primary targets of fibrogenic stimuli in the injured liver. During the development of fibrosis, HSC undergo a transition from resting vitamin A-rich cells to an activated myofibroblastic phenotype characterized by loss of vitamin A, expression of $\alpha$ - smooth muscle actin, enhanced proliferation and increased production of various extracellular matrix components [1-4]. Activation of HSC has been identified as a central event in hepatic fibrosis and is regulated by a wide variety of molecules including cytokines, cell-surface receptors, signal transduction molecules and factors that 


\section{A Cytoplasm}
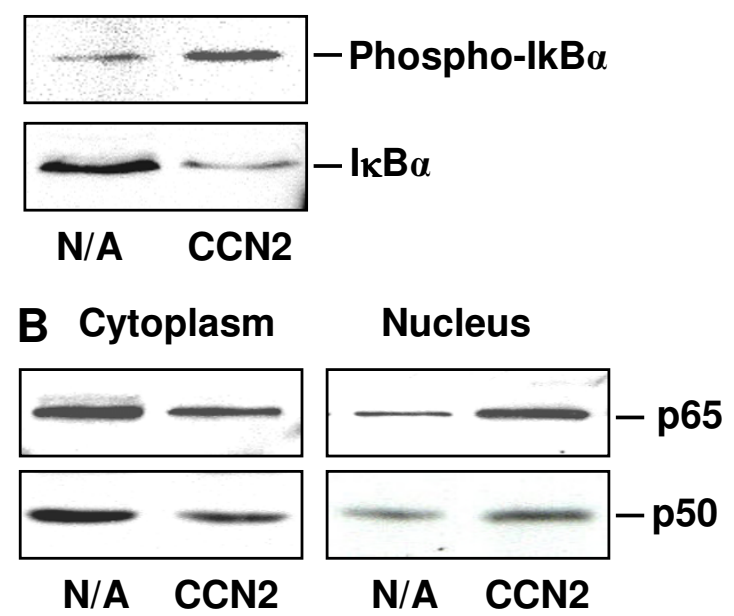

Figure I

Effect of CCN2 on stimulation of I $\kappa B \alpha$ phophorylation and NF- $\kappa$ B translocation. Freshly isolated rat HSC were cultured for $24 \mathrm{~h}$ in 5\% FBS DMEM and for another 48 $\mathrm{h}$ in serum-free medium. The cells were harvested following incubating the cells for $30 \mathrm{~min}$ in the absence or presence of $100 \mathrm{ng} / \mathrm{ml} \mathrm{CCN2}$, and nuclear extracts were prepared.

Western blot analysis shows that CCN2 induces IKB phosphorylation and degradation (A) and translocation of the NF$\kappa B$ subunits $p 65 / p 50$ from cytoplasm to nucleus (B).

regulate HSC gene expression at the transcriptional and post-transcriptional levels [3-6].

Connective tissue growth factor (CCN2, also known as CTGF) is a cysteine-rich matricellular protein that regulates cell adhesion, migration, proliferation, survival, and differentiation [7]. It has fibrogenic properties in vitro and is over-expressed in many fibrotic lesions, including those of the skin, lung, kidney and liver [8-12]. CCN2 production is enhanced during progressive activation of primary rat HSC in vitro as well as by transforming growth factor- $\beta$ [11-13]. CCN2 induces migration, proliferation and adhesion of HSC as well as enhanced expression of type I collagen [14-19].

Transcription factor NF- $\mathrm{KB}$ is a key regulator of the growth, differentiation, and fate of mammalian cells [20]. NF- $\kappa B$ exists in virtually all cell types and represents a family of inducible transcription factors that are activated by a variety of stimuli including viral infection, lipopolysaccharide, oxidative stress, and cytokines [21]. The active form of NF- $\kappa B$ is found in the nucleus as either a heterodimer or a homodimer composed of five members of the Rel family of proteins (p65, p50, p52, c-Rel, and RelB) [20]. It has recently been reported that transcriptional repressor CBF1 plays a key role in regulating NF- $\kappa B$ activ- ity through its interaction with a dual NF- $\kappa B / C B F 1-b i n d-$ ing site in the $\mathrm{I} \kappa \mathrm{B} \alpha$ promoter $[22,23]$. I $\mathrm{I} \mathrm{B} \alpha$ regulates NF$\kappa \mathrm{B}$ activity by directly interacting with the transcriptional factor to form inactive complexes that are located to the cytoplasm. Following specific signaling, phosphorylation

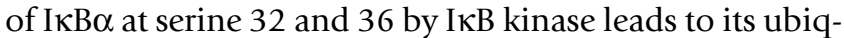
uitinylation and degradation by the proteasome, and transport of active NF- $\kappa \mathrm{B}$ to nucleus [24]. Active NF- $\kappa \mathrm{B}$ is involved in the expression of numerous cytokines, acute phase response proteins, adhesion molecules and Rel/IкB proteins [20]. Also, when NF- $\kappa \mathrm{B}$ activation is prevented or inhibited, cells undergo enhanced apoptosis showing that active NF- $\kappa \mathrm{B}$ exerts a cytoprotective role by inhibiting apoptosis [25].

Several studies have compared NF- $\kappa \mathrm{B}$ activity in quiescent versus activated HSC [26-28]. NF- $\kappa \mathrm{B}$ activity is increased in cultured activated HSC but it is not required for either cell proliferation or the process of activation. In contrast, active NF- $\kappa \mathrm{B}$ plays an important role in preventing apoptosis of activated HSC [26,29]. Understanding mechanisms of HSC survival may provide the basis for novel anti-fibrotic therapies that focus on the ability to clear activated HSC from the liver by inducing them to undergo apoptosis. Since the principal CCN2 receptor on HSC is integrin $\alpha_{v} \beta_{3}$ [19], which is intimately associated with HSC survival [30], we have investigated the role of CCN2 in NF- $\kappa \mathrm{B}$ activation and HSC survival.

\section{Results}

CCN2 induces phosphorylation of I KB $\alpha$ and translocation of $N F-\kappa B$

In most cell types, NF- $\kappa \mathrm{B}$ is found in the cytoplasm as an inactive dimer bound to one of the I $\mathrm{B} B$ inhibitory proteins

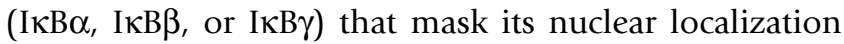
signal. As assessed by Western blotting of cytoplasmic protein extracts day 4 primary HSC, phospho-I $\mathrm{KB} \alpha$ was elevated while total I $\kappa \mathrm{B} \alpha$ was decreased following stimulation by CCN2 (Figure 1A), indicating that CCN2 could induce I $\mathrm{B} \alpha$ phosphorylation and degradation. Additionally, following CCN2 stimulation, levels of p65 and p50 were reduced in the cytoplasm but increased in the nucleus (Figure 1B), consistent with the notion that CCN2-induced I $\mathrm{IB} \alpha$ phosphorylation and degradation was associated with translocation of cytoplasmic NF- $\kappa \mathrm{B}$ to the nucleus.

\section{CCN2 promotes NF-KB DNA binding activity}

To further explore whether active NF- $\kappa \mathrm{B}$ can bind to its target DNA sequence and activate gene transcription in response to CCN2 stimulation, NF- $\kappa \mathrm{B}$ DNA binding activity was determined by EMSA following incubation of HSC nuclear protein extracts with ${ }^{32} \mathrm{P}$-labeled NF- $\kappa \mathrm{B}$ oligomers containing NF- $\mathrm{KB} / \mathrm{CBF} 1$ binding sites. Two complexes were significantly enhanced by $\mathrm{CCN} 2$, reaching a plateau 


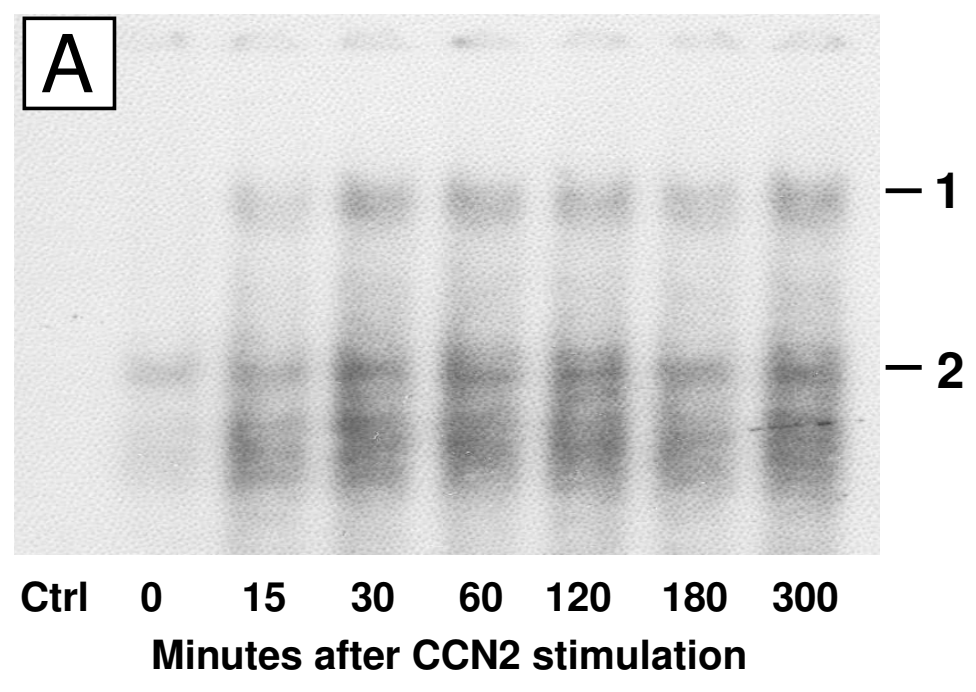

NF- $\kappa B$ wt

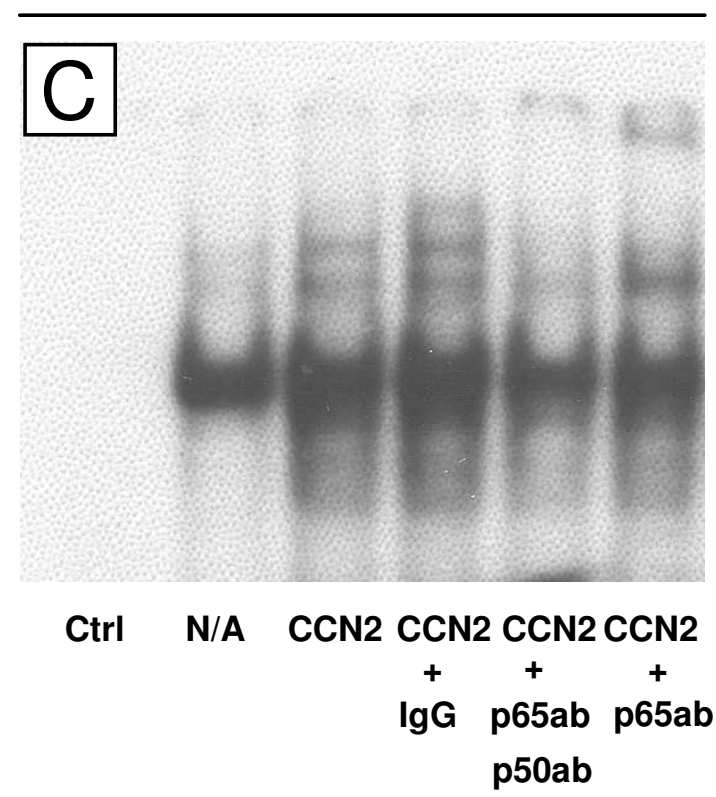

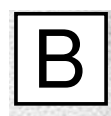

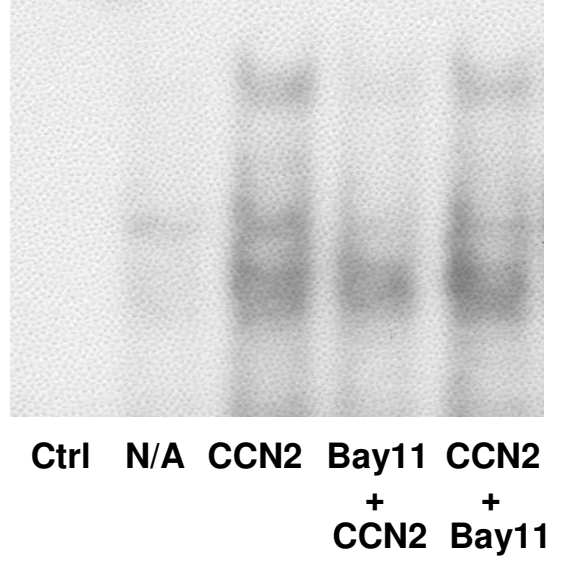

CBF-1 p50/65 mut mut

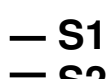

- 52

- p65/p65

- p65/p50

- p50/p50

- CBF-1
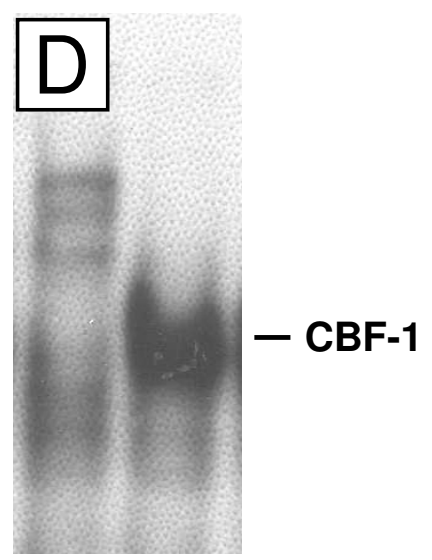

CCN2 CCN2

\section{Figure 2}

Modulation of NF- $\kappa$ B DNA binding activity by CCN2. HSC were harvested at the desired time points after treatment with or without $100 \mathrm{ng} / \mathrm{ml} \mathrm{CCN2.6 \mu g} \mathrm{nuclear}$ protein extract were used in $20 \mu \mathrm{l}$ reactions, containing $0.2 \mathrm{ng} 32 \mathrm{P}$-labeled double strand NF- $\kappa B$ oligonucleotides. Reactions were fractioned through a nondenaturing $4 \%$ polyacrylamide gel. (A) Complex I (p65/p50) and complex 2 were enhanced after stimulation with CCN2. "Ctrl" represents a reaction lacking nuclear extract. (B) Bay I I-7082 inhibited complex formation when added prior to CCN2 treatment ("Bay II + CCN2") but not when added subsequent to a I hour pretreatment with CCN2 ("CCN2 + Bayl I"). (C) A supershift assay was performed by incubating preassembled gel shift assay complexes containing $8 \mu \mathrm{g}$ nuclear extract with either $2 \mu \mathrm{g}$ normal rabbit lgG or $2 \mu \mathrm{g}$ anti-NF- $\mathrm{kB}$ antibody prior to separation through $8 \%$ polyacrylamide gel, showing that CCN2 stimulates the formation of an anti-p65/p65/antip50/p50/NF- $\kappa$ B oligonucleotide (SI) and an anti-p65/p65/NF- $\kappa B$ oligonucleotide (S2) supershift complexes. (D) A gel shift assay was performed following pre-incubating the nuclear extracts with either $32 \mathrm{P}$-labeled $\mathrm{p} 50 / \mathrm{p} 65$ site mutant oligonucleotides or CBF-I site mutant oligonucleotides. 

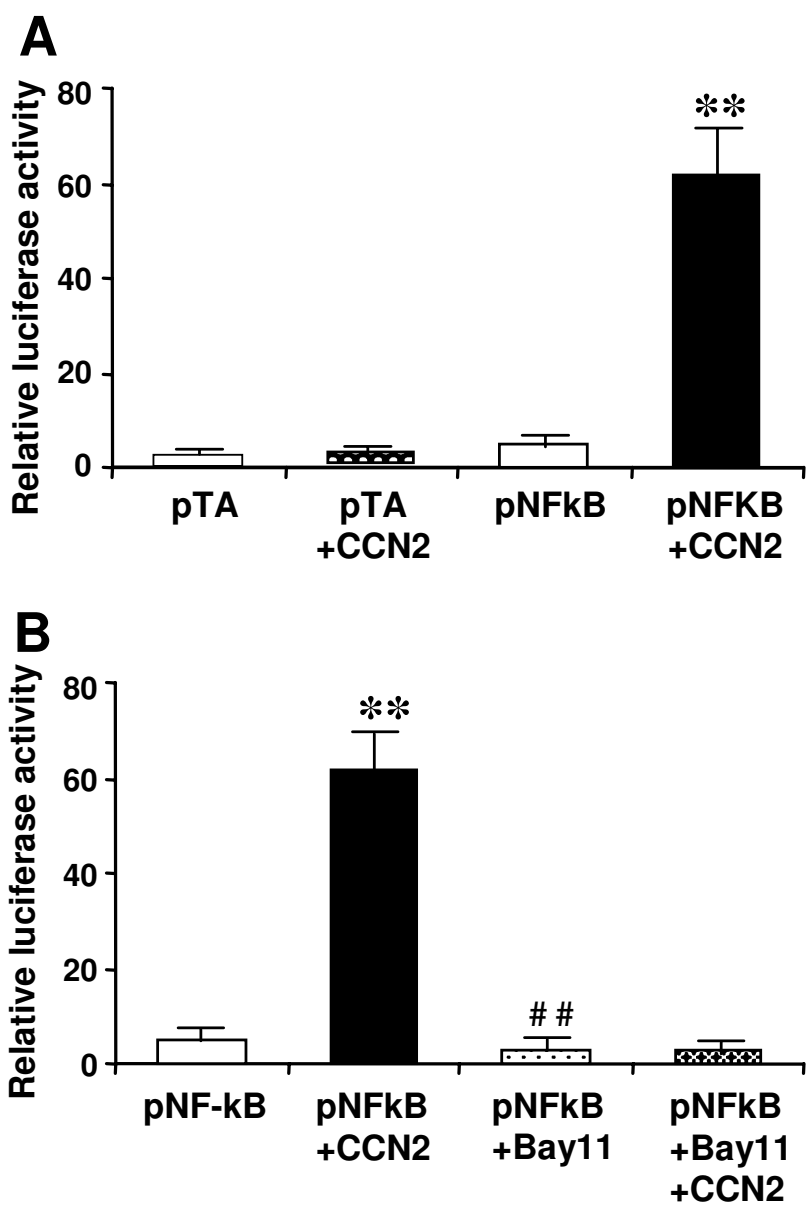

Figure 3

Effect of CCN2 on expression of NF- $K B$ response genes. (A) Freshly isolated rat HSC were placed in 12-well plates, transfected with I $\mu \mathrm{g}$ PTA-Luc or pNF-KB-Luc, and then incubated for another $24 \mathrm{~h}$ in the absence or presence of $100 \mathrm{ng} / \mathrm{ml} \mathrm{CCN2}$. (B) Transfected cells were pre-treated with $10 \mu \mathrm{M}$ Bay I I-7082 for $30 \mathrm{~min}$ and cultured for another $24 \mathrm{~h}$ in the absence or presence of $100 \mathrm{ng} / \mathrm{ml} \mathrm{CCN} 2$. **P $<$

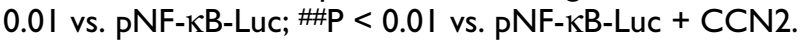

about 30 min after CCN2 addition (Fig. 2A). The NF-кB inhibitor, Bay11-7082, prevented complex formation when added to the cells prior to CCN2 treatment but not when added after CCN2 treatment (Figure 2B). As shown in Figure $2 \mathrm{C}$, active NF- $\kappa \mathrm{B}$ induced by CCN2 comprised three separate dimers (p65/p65, p65/p50 and p50/p50) based on the fact that a supershift (S1) was obtained with anti-p65 and anti-p50 antibodies with the concomitant disappearance of all three bands and that a supershift (S2) with anti-p65 antibody was associated with loss of the top two bands. Three dimers of NF- $\mathrm{KB}$ induced by CCN2 were also demonstrated following incubation of the nuclear extract with a CBF-1 mutant oligonucleotide probe but not with a p50/p65 mutant oligonucleotide probe (Figure $2 \mathrm{D})$. These results indicate that $\mathrm{CCN} 2$ induces activation of NF- $\kappa B$ and its assembly into three dimers that individually bind to NF- $\kappa \mathrm{B}$ DNA binding site.

\section{Effect of CCN2 on expression of NF- $\kappa B$ target genes}

To explore the effect of CCN2 on transcriptional signaling by NF- $\kappa \mathrm{B}$, day 4 primary HSC cultures were transfected with luciferase reporter genes driven by either a minimal promoter alone (pTA) or together with four tandem copies of the NF- $\kappa \mathrm{B}$ DNA binding sites $(\mathrm{pNF}-\kappa \mathrm{B})$ that were identical to those used for the EMSA studies. $\mathrm{pNF}-\kappa \mathrm{B}$ generated 1.5-fold higher luciferase activities than pTA in HSC, whereas, the luciferase activities of $\mathrm{pNF}-\mathrm{\kappa B}$ in the cells following stimulation with CCN2 were 13-fold higher than control cells (Figure 3A). CCN2-mediated elevation of $\mathrm{pNF}-\kappa \mathrm{B}$ luciferase activity was completely abrogated by treatment of the cells with Bay11-7082, a specific inhibitor of I $\kappa \mathrm{B} \alpha$ phosphorylation (Figure $3 \mathrm{~B}$ ), suggesting that $\mathrm{CCN} 2$ modulates the transcriptional and translational event of NF- $\kappa \mathrm{B}$ target genes via NF- $\kappa \mathrm{B}$ signaling pathway.

\section{CCN2 sustains HSC survival through NF- $\kappa B$ signaling pathway}

To examine the effect of CCN2 on the fate of HSC, day 4primary HSC cultures were treated with or without CCN2 for $24 \mathrm{~h}$. Cell viability was determined by Trypan blue exclusion or by luminescent assessment of cellular ATP levels. As shown in Figures $4 \mathrm{~A}$ and $4 \mathrm{~B}$, each assay showed that HSC viability was significantly elevated by CCN2. To determine if the NF- $\mathrm{KB}$ pathway was involved in this effect, Bay11-7082 was added to HSC cultures. As mentioned above, when added prior to CCN2, the inhibitor completely blocked the ability of CCN2 to stimulate NF$\kappa \mathrm{B}$ DNA binding activity whereas it had little inhibitory effect on DNA binding activity in cells that has been pretreated with CCN2 (Figure 2B). While Bay11-7082 inhibited cell survival as expected, it had little inhibitory effect in cells that had been pre-treated with CCN2 (Figure $4 \mathrm{~A}, \mathrm{~B})$, consistent with the data shown in Figure $2 \mathrm{~B}$ and supportive of the notion that prior stimulation of NF- $\kappa B$ by CCN2 was sufficient to overcome the effects of subsequently blocking NF- $\kappa$ B with Bay 11. Similarly, Bay-11induced caspase-3 activity in HSC was reduced as much as $25 \%$ in CCN2-stimulated cells, consistent with the ability of CCN2 to rescue cells from apoptosis (Figure 4C).

Collectively, these data suggest that CCN2 is a survival factor for HSC and that survival is regulated via NF- $\kappa \mathrm{B}$ signaling.

\section{Discussion}

CCN2 has emerged as a key mediator of fibrosis in both acute and chronic diseases [8-12]. In the liver, CCN2 
expression is associated with hepatic fibrosis in both human subjects and animal models [10-12,14,17,31]. CCN2 appears to be directly involved in HSC biology as it is produced as a function of activation or exposure the cells to various fibrogenic stimuli including transforming growth factor- $\beta$, platelet-derived growth factor, alcohol and acetaldehyde [14]. Additionally, CCN2 promotes HSC adhesion, migration, proliferation, and synthesis of collagen type I $[14,19]$, all of which are properties of activated HSC. [1-4,32]. Activation of HSC is regulated by several soluble factors, including growth factors, cytokines, and products of oxidative stress, as well as by extensive changes in the composition and organization of the extracellular matrix. HSC activation has previously been linked to activation of NF- $\kappa B$ while over-expression of I $\mathrm{B} B \alpha$ in HSC has been shown to suppress NF- $\kappa B$ activation [2629]. Our data show that serum-starved day 4 HSC demonstrate very low levels of nuclear NF-KB and no detectable DNA-binding activity. Following CCN2 stimulation, a marked nuclear translocation of NF- $\mathrm{KB}$ was evident along with a persistent DNA binding activity of its three dimers, and an induction of IкB $\alpha$ phosphorylation and degradation. Collectively, these data show that $\mathrm{CCN} 2$ activates the $\mathrm{NF}-\mathrm{KB}$ signaling pathway in HSC. Moreover, as assessed using a NF-KB reporter construct, we showed that NF- $\mathrm{KB}$ response gene expression is induced by $\mathrm{CCN} 2$ in day 4 cultured HSC and support previous findings that NF- $\mathrm{KB}$ response genes are induced in activated HSC $[26,29]$.

Apoptosis has been described as the nexus between liver injury and fibrosis [33] and increasing evidence suggests that NF- $\mathrm{KB}$ is involved in survival pathways in multiple

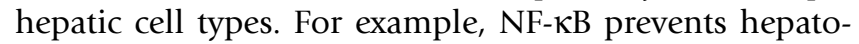
cyte apoptosis following liver regeneration or exposure to tumor necrosis factor- $\alpha$ [34-36]. In addition, NF- $\mathrm{KB}$ also protects hepatocarcinoma cells or activated HSC from apoptosis $[26,29,37]$. Consistent with this latter observation, we showed that CCN2 promoted HSC survival and that NF- $\mathrm{KB}$ was involved in the response as shown by the finding that pretreatment of HSC with CCN2 protected the cells from Bay11-7082-induced decreased cell survival and increased caspase- 3 activity.

The ability of CCN2 to sustain HSC survival supports previous observations showing that CCN2 is a survival factor for other cell types such as endothelial cells or chicken embryo fibroblasts $[38,39]$. Additionally, the related molecule, CCN1 (also known as CYR61) promotes anti-apoptotic pathways when over-expressed in breast cancer MCF7 cells in an integrin-dependent manner [40], consistent with the recognition of integrins as signaling receptors for $\mathrm{CCN}$ proteins [41]. In the case of HSC, the principal CCN2 receptor is integrin $\alpha_{v} \beta_{3}[19]$ which transduces survival signals in activated HSC [30] as well as during angiogenesis, wound healing, osteoporosis, and
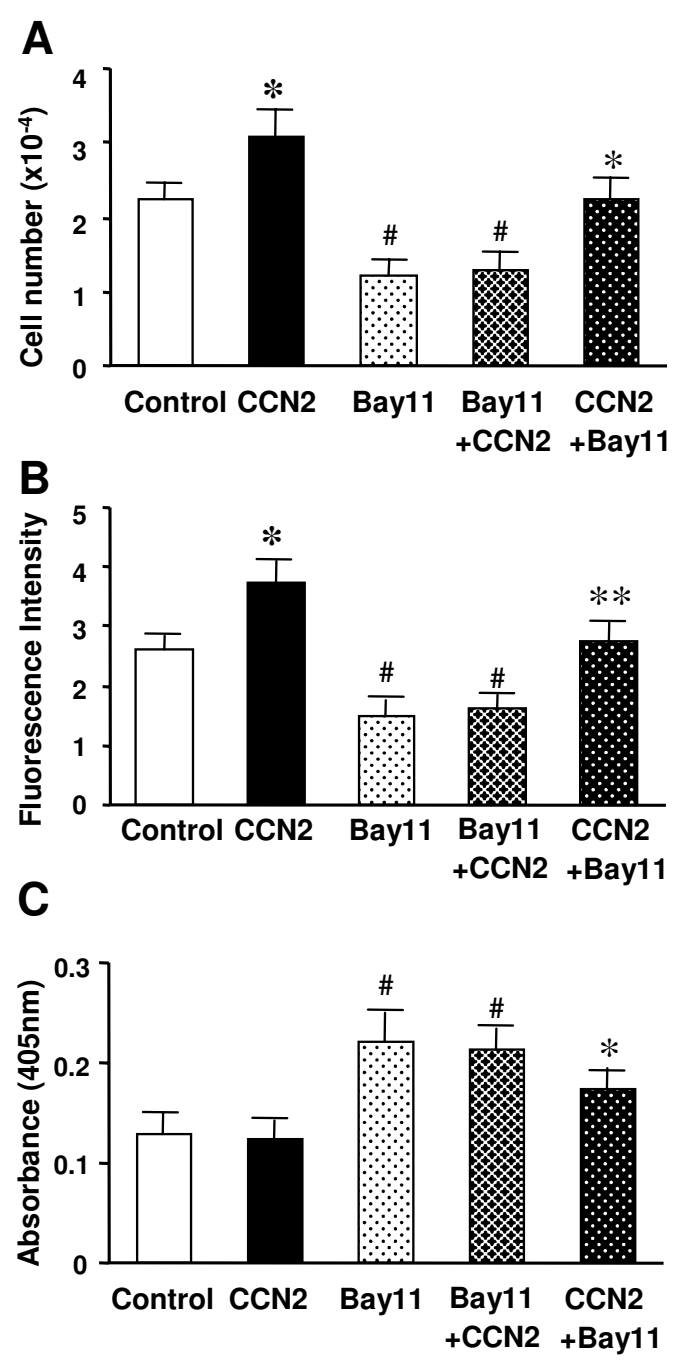

\section{Figure 4}

Effect of CCN2 in sustaining HSC survival. Freshly isolated rat HSC were cultured in 6-well plates in $5 \%$ FBS

DMEM for $24 \mathrm{~h}$, followed by serum deprivation for $48 \mathrm{~h}$. The cells were cultured for another $24 \mathrm{~h}$ in the absence or presence of $100 \mathrm{ng} / \mathrm{ml} \mathrm{CCN2}$ ("CCN2"). In the CCN2 protection assay, the cells were incubated with $10 \mu \mathrm{M}$ Bay I I-7082 for $24 \mathrm{~h}$ alone ("Bayl I") or following pre-treatment of the cells with CCN2 for I h ("CCN2+Bay I I"). For the Bay I I blocking assay, the cells were pre-treated with Bayl I-7082 for 30 min and cultured for another $24 \mathrm{~h}$ in the presence of $100 \mathrm{ng} / \mathrm{ml}$ CCN2 ("Bayl I+CCN2"). At the end of incubation time period, (A) cells were trypsinized and survival was determined by Trypan blue exclusion, or (B) cell viability was also quantified by measurement of the fluorescence intensity using CellTiter-Glo ${ }^{\mathrm{TM}}$ reagent, or (C) cell apoptosis was assessed by measurement of caspase-3 activity at $405 \mathrm{~nm}$ using a luminescence assay kit. $* \mathrm{P}<0.05$ vs. control; $\# \mathrm{P}<$ 0.05 vs. CCN2 group; **P $<0.01$ and $* \mathrm{P}<0.05$ vs. BaylI7082 group. 
tumor metastasis [42-51]. Apoptosis in HSC is inhibited by engagement of integrin $\alpha_{v} \beta_{3}$ [30] and disruption of integrin-mediated HSC adhesion leads to induction of apoptosis [52]. Since expression of CCN2 and integrins is enhanced during HSC activation and liver fibrosis [5357], persistence of the activated fibrogenic phenotype in HSC may occur, at least in part, by NF- $\kappa B$ survival pathways that are triggered via the binding of CCN2 to its integrin $\alpha_{v} \beta_{3}$ receptor.

Activation of HSC is also associated with the expression of death receptors such as Fas and TRAIL-R2, suggesting that HSC fate is likely determined by a balance between survival and apoptotic stimuli [33]. For example, HSC undergo apoptosis following treatment with nerve growth factor, a response that is due to the expression of the p75 nerve growth factor receptor [58] which has recently been implicated as a CCN2 signaling molecule in kidney mesangial cells [59]. Furthermore, pro-apoptotic effects of CCN2 have been reported in vascular smooth muscle cells and breast cancer cells, although the underlying mechanisms have yet to be understood [60-62]. Thus, depending on the presence and activity of its cognate cell surface receptors and their associated signaling pathways, CCN2 may be able to drive either apoptosis or survival in HSC. This points to a complex scenario whereby CCN2 may exert apparently opposing or contradictory effects on HSC viability, and future investigations will need to clarify this issue. Nonetheless, clinical fibrosis is now regarded as a largely reversible process that is strongly linked to apoptosis of activated HSC [33,63] and our data showing that $\mathrm{CCN} 2$ can promote HSC survival via NF- $\mathrm{BB}$ provide support for the development of new anti-fibrotic strategies that target CCN2, its receptors, or its signaling pathways.

\section{Conclusion}

In addition to promoting HSC fibrogenesis [17], CCN2 confers a survival advantage on HSC which is attributable, at least in part, to its ability to activate NF- $\kappa \mathrm{B}$ signaling pathways in the cells.

\section{Methods}

\section{Isolation and culture of HSC}

In a protocol approved by the Institutional Animal Care and Use Committee of Children's Research Institute, Columbus, $\mathrm{OH}$, primary HSC were isolated from normal male Sprague-Dawley rats as described [19]. Cells were grown in Dulbecco's modified Eagle's medium (DMEM; Gibco, Grand Island, NY, USA) supplemented with 10\% fetal bovine serum (FBS), $100 \mathrm{U} / \mathrm{ml}$ penicillin and 100 $\mu \mathrm{g} / \mathrm{ml}$ streptomycin. Cells were placed in $20 \times 100 \mathrm{~mm}$ cell culture dishes (Falcon; Becton Dickinson, Franklin Lakes, NJ, USA) for nuclear extraction, 6-well tissue culture plates (Falcon) for Western blot and for cell viability assays, 12-well tissue culture plates (Falcon) for luciferase reporter gene transfection. The cells were then cultured DMEM/5\% FBS for $24 \mathrm{~h}$, followed by serum-free medium for $48 \mathrm{~h}$. On day 4 , the cells were treated with or without $100 \mathrm{ng} / \mathrm{ml} \mathrm{CCN2}$, and harvested at the desired time points. Human recombinant $38 \mathrm{kDa} C \mathrm{CN} 2$ was produced in a Chinese hamster ovary cell expression system as described [15].

\section{Electrophoretic mobility shift assay (EMSA)}

Nuclear extracts were prepared as described [64]. 32P-endlabeled double-stranded oligonucleotide probes used in this study comprised either wild type NF- $\kappa$ B oligonucleotide (sense: 5'-tgaggggactttcccagg-3'), p50/p65 mutant oligonucleotide (sense: 5'-tgaggcgactttcccagg-3') or CBF1mutant oligonucleotide (sense: 5'-tgaggggacttcccgagg-3') [23]. The double-stranded NF- $\mathrm{KB}$ oligmers were used in nuclear protein-DNA binding reactions (20 $\mu$ l volume) in which $1 \mu \mathrm{g}$ poly $\mathrm{dI}: \mathrm{dC}$ and $6 \mu \mathrm{g}$ nuclear protein extract were incubated for $20 \mathrm{~min}$ at $4^{\circ} \mathrm{C}$ prior to addition of 0.2 ng ${ }^{32} \mathrm{P}$-labled double-stranded oligonucleotide for $30 \mathrm{~min}$ at $4{ }^{\circ} \mathrm{C}$. The contents of each tube were electrophoresed on non-denaturing $4 \%$ polyacrylamide gels which were then dried and analyzed by autoradiography. Supershift assays were performed by incubating pre-assembled gel shift assay complexes containing $8 \mu \mathrm{g}$ nuclear extract with either $2 \mu \mathrm{g}$ rabbit normal IgG, $2 \mu \mathrm{g}$ rabbit polyclonal antip65 NF- $\mathrm{KB}$ IgG or/and $2 \mu \mathrm{g}$ rabbit polyclonal anti- p50 NF- $\kappa \mathrm{B}$ IgG (Santa Cruz Biotechnology Inc, CA, USA) for 2 $\mathrm{h}$ at $4^{\circ} \mathrm{C}$ before electrophoresis. The samples were then electrophoresed on $8 \%$ polyacrylamide gels [65].

\section{Transfections and luciferase assay}

HSC were transfected with pNF- $\mathrm{BB}$-Luc or pTA-Luc control vector using Superfect transfection reagent (QIAGEN, Valencia, CA, USA) under serum-free conditions for $3 \mathrm{~h}$. The transfected cells were incubated for another $24 \mathrm{~h}$ in the absence or presence of $100 \mathrm{ng} / \mathrm{ml} \mathrm{CCN} 2$. After normalization of transfection efficiency by $\beta$-galactosidase expression, luciferase enzyme activity was then quantified using a reporter assay kit (Clontech, Palo Alto, CA, USA).

\section{SDS-PAGE and immunoblotting}

$25 \mu \mathrm{g}$ cytoplasmic or nuclear extracts (see above) were subjected to SDS-PAGE in 5-15\% gradient gels at $120 \mathrm{~V}$ for $1.5 \mathrm{~h}$. Proteins were transferred to nitrocellulose membranes which were individually incubated with 1:500 dilutions of rabbit anti-I $\kappa \mathrm{B} \alpha$, -phospho-I $\kappa \mathrm{B} \alpha,-\mathrm{NF}-\kappa \mathrm{B}$ p65, or $-\mathrm{NF}-\kappa \mathrm{B}$ p50 polyclonal IgG (Santa Cruz Biotechnology Inc, CA, USA) in 5\% nonfat milk TBST for $24 \mathrm{~h}$ at $4^{\circ} \mathrm{C}$. The filters were then incubated with $1: 1000$ dilutions of HRP-conjugated goat anti-rabbit IgG for $1 \mathrm{~h}$ at room temperature. The membrane was washed extensively before detection using chemiluminescence. 


\section{Cell viability assay}

Freshly isolated HSC were placed in 6-well tissue culture plates and incubated in DMEM/5\% FBS for $24 \mathrm{~h}$ followed by serum-free medium for $48 \mathrm{~h}$. The cells were incubated for an additional $24 \mathrm{~h}$ in the absence or presence of 100 $\mathrm{ng} / \mathrm{ml}$ CCN2. In CCN2 protection assays, $10 \mu \mathrm{M}$ Bay117082 was added to the medium either alone or following treatment of the cells with CCN2 for $1 \mathrm{~h}$. At the end of the incubation period, the cells were trypsinized, mixed 1:1 with Trypan Blue solution (Sigma) and counted within 3 minutes under light microscopy using a hemocytometer.

In an alternative approach for measurement of cell viability, the CellTiter-Glo ${ }^{\mathrm{TM}}$ Luminescent assay kit was employed to assess the relative levels of cellular ATP. At the end of the incubation period, cells were treated with CellTiter-Glo $^{\mathrm{TM}}$ reagent according to the manufacturer's instructions. Fluorescence was measured using black/clear tissue culture plates (BD Biosciences, Bedford, MA, USA). Cell viability was quantified by measurement of the sample fluorescence intensity at $560_{\mathrm{EX}} / 590_{\mathrm{EM}}$.

\section{Caspase-3 activity assay}

Freshly isolated HSC were placed in 12-well tissue culture plate, and incubated in DMEM/5\% FBS for $24 \mathrm{~h}$ followed by serum-free medium for $48 \mathrm{~h}$. The cells were incubated for an additional $24 \mathrm{~h}$ in the presence or absence of 100 $\mathrm{ng} / \mathrm{ml} \mathrm{CCN} 2$. $10 \mu \mathrm{M}$ Bay11-7082 was added to the medium either alone or following treatment the cells with CCN2 for $1 \mathrm{~h}$. Protein extracts were prepared following manufacturer's instructions. Caspase-3 activity was measured using an assay kit (Promega, Madison, WI, USA) in which cell extracts were mixed with Ac-DEVD-pNA substrate for 1 -hour incubation at $30^{\circ} \mathrm{C}$ in 96-well microtiter plates prior to colorimetric measurement of p-nitroanilide product at $405 \mathrm{~nm}$.

\section{Statistical analysis}

Data are presented as mean \pm SE. Differences were analyzed statistically with paired sample student's t-test.

\section{Competing interests}

The author(s) declare that they have no competing interests.

\section{Authors' contributions}

RG carried out the experiments and wrote the draft manuscript. DRB participated in the experimental design and edited the manuscript.

\section{Acknowledgements}

This work was supported by $\mathrm{NIH}$ grant AAI 2817 awarded to D.R.B.

\section{References}

I. Gressner AM, Bachem MG: Cellular communications and cell-matrix interactions in the pathogenesis of fibroproliferative diseases: liver fibrosis as a paradigm. Ann Biol Clin (Paris) 1994, 52(3):205-226.

2. Pinzani $M$ : Novel insights into the biology and physiology of the Ito cell. Pharmacol Ther 1995, 66(2):387-4I2.

3. Eng FJ, Friedman SL: Fibrogenesis I. New insights into hepatic stellate cell activation: the simple becomes complex. Am J Physiol Gastrointest Liver Physiol 2000, 279(I):G7-GI I.

4. Friedman SL: Molecular regulation of hepatic fibrosis, an integrated cellular response to tissue injury. J Biol Chem 2000, 275(4):2247-2250

5. Pinzani M, Gesualdo L, Sabbah GM, Abboud HE: Effects of plateletderived growth factor and other polypeptide mitogens on DNA synthesis and growth of cultured rat liver fat-storing cells. J Clin Invest 1989, 84(6): I 786-I793.

6. Friedman SL: Cytokines and fibrogenesis. Semin Liver Dis 1999, I9(2): I29-140.

7. Brigstock DR: The connective tissue growth factor/cysteinerich $6 \mathrm{I}$ /nephroblastoma overexpressed (CCN) family. Endocr Rev 1999, 20(2): 189-206.

8. Igarashi A, Nashiro K, Kikuchi K, Sato S, Ihn H, Fujimoto M, Grotendorst GR, Takehara K: Connective tissue growth factor gene expression in tissue sections from localized scleroderma, keloid, and other fibrotic skin disorders. J Invest Dermatol 1996, I 06(4):729-733.

9. Lasky JA, Ortiz LA, Tonthat B, Hoyle GW, Corti M, Athas G, Lungarella G, Brody A, Friedman M: Connective tissue growth factor mRNA expression is upregulated in bleomycin-induced lung fibrosis. Am J Physiol 1998, 275(2 Pt I):L365-7I.

10. Abou-Shady M, Friess H, Zimmermann A, di Mola FF, Guo XZ, Baer $\mathrm{HU}$, Buchler MW: Connective tissue growth factor in human liver cirrhosis. Liver 2000, 20(4):296-304.

II. Williams EJ, Gaca MD, Brigstock DR, Arthur MJ, Benyon RC: Increased expression of connective tissue growth factor in fibrotic human liver and in activated hepatic stellate cells. J Hepatol 2000, 32(5):754-76I

12. Paradis V, Dargere D, Vidaud M, De Gouville AC, Huet S, Martinez V, Gauthier JM, Ba N, Sobesky R, Ratziu V, Bedossa P: Expression of connective tissue growth factor in experimental rat and human liver fibrosis. Hepatology 1999, 30(4):968-976.

13. Gao R, Brigstock DR: Low density lipoprotein receptor-related protein (LRP) is a heparin-dependent adhesion receptor for connective tissue growth factor (CTGF) in rat activated hepatic stellate cells. Hepatol Res 2003, 27(3):2| 4-220.

14. Paradis V, Dargere D, Bonvoust F, Vidaud M, Segarini P, Bedossa P. Effects and regulation of connective tissue growth factor on hepatic stellate cells. Lab Invest 2002, 82(6):767-774.

15. Ball DK, Moussad EE, Rageh MA, Kemper SA, Brigstock DR: Establishment of a recombinant expression system for connective tissue growth factor (CTGF) that models CTGF processing in utero. Reproduction 2003, I 25(2):27|-284.

16. Ball DK, Rachfal AW, Kemper SA, Brigstock DR: The heparin-binding $10 \mathrm{kDa}$ fragment of connective tissue growth factor (CTGF) containing module 4 alone stimulates cell adhesion. J Endocrinol 2003, I 76(2):RI-7.

17. Rachfal AW, Brigstock DR: Connective tissue growth factor (CTGF/CCN2) in hepatic fibrosis. Hepatol Res 2003, 26(I): I-9.

18. Gao R, Ball DK, Perbal B, Brigstock DR: Connective tissue growth factor induces c-fos gene activation and cell proliferation through p44/42 MAP kinase in primary rat hepatic stellate cells. J Hepatol 2004, 40(3):431-438.

19. Gao R, Brigstock DR: Connective tissue growth factor (CCN2) induces adhesion of rat activated hepatic stellate cells by binding of its C-terminal domain to integrin \{alpha\} $\mathbf{v}\{$ beta\} 3 and heparan sulfate proteoglycan. I Biol Chem 2004, 279( ( 0):8848-8855.

20. Ghosh S, May MJ, Kopp EB: NF-kappa B and Rel proteins: evolutionarily conserved mediators of immune responses. Annu Rev Immunol 1998, I 6:225-260.

21. Ghosh S, Karin M: Missing pieces in the NF-kappaB puzzle. Cell 2002, I 09 Suppl:S8I-96.

22. Berti R, Williams AJ, Moffett JR, Hale SL, Velarde LC, Elliott PJ, Yao C, Dave JR, Tortella FC: Quantitative real-time RT-PCR analysis of inflammatory gene expression associated with 
ischemia-reperfusion brain injury. J Cereb Blood Flow Metab 2002, 22(9): 1068-1079.

23. Oakley F, Mann J, Ruddell RG, Pickford J, Weinmaster G, Mann DA: Basal expression of IkappaBalpha is controlled by the mammalian transcriptional repressor RBP-J (CBFI) and its activator Notch I. J Biol Chem 2003, 278(27):24359-24370.

24. Mann DA, Smart DE: Transcriptional regulation of hepatic stellate cell activation. Gut 2002, 50(6):89 |-896.

25. Sonenshein GE: Rel/NF-kappa B transcription factors and the control of apoptosis. Semin Cancer Biol I997, 8(2): I I3-II9.

26. Elsharkawy AM, Wright MC, Hay RT, Arthur MJ, Hughes T, Bahr MJ, Degitz K, Mann DA: Persistent activation of nuclear factor-kap$\mathrm{paB}$ in cultured rat hepatic stellate cells involves the induction of potentially novel Rel-like factors and prolonged changes in the expression of IkappaB family proteins. Hepatology 1999, 30(3):761-769.

27. Hellerbrand C, Jobin C, Licato LL, Sartor RB, Brenner DA Cytokines induce NF-kappaB in activated but not in quiescent rat hepatic stellate cells. Am J Physiol 1998, 275(2 Pt I):G269-78.

28. Rippe RA, Schrum LW, Stefanovic B, Solis-Herruzo JA, Brenner DA: NF-kappaB inhibits expression of the alphal(I) collagen gene. DNA Cell Biol 1999, I 8(1 0):75I-76I.

29. Lang A, Schoonhoven R, Tuvia S, Brenner DA, Rippe RA: Nuclear factor kappaB in proliferation, activation, and apoptosis in rat hepatic stellate cells. J Hepatol 2000, 33(I):49-58.

30. Zhou X, Murphy FR, Gehdu N, Zhang J, Iredale JP, Benyon RC: Engagement of alpha Vbeta 3 integrin regulates proliferation and apoptosis of hepatic stellate cells. J Biol Chem 2004

31. Hayashi N, Kakimuma T, Soma Y, Grotendorst GR, Tamaki K, Harada $M$, Igarashi $A$ : Connective tissue growth factor is directly related to liver fibrosis. Hepatogastroenterology 2002 49(43): 133-135.

32. Gaca MD, Zhou X, Benyon RC: Regulation of hepatic stellate cell proliferation and collagen synthesis by proteinase-activated receptors. J Hepatol 2002, 36(3):362-369.

33. Canbay A, Friedman S, Gores G]: Apoptosis: the nexus of liver injury and fibrosis. Hepatology 2004, 39(2):273-278.

34. limuro Y, Nishiura T, Hellerbrand C, Behrns KE, Schoonhoven R, Grisham JW, Brenner DA: NFkappaB prevents apoptosis and liver dysfunction during liver regeneration. J Clin Invest 1998, I0I(4):802-8I I.

35. Black D, Bird MA, Hayden M, Schrum LW, Lange P, Samson $C$ Hatano E, Rippe RA, Brenner DA, Behrns KE: TNF alpha-induced hepatocyte apoptosis is associated with alterations of the cell cycle and decreased stem loop binding protein. Surgery 2004, I 35(6):619-628

36. Imose M, Nagaki M, Naiki T, Osawa Y, Brenner DA, Asano T, Hayash $\mathrm{H}$, Kato T, Moriwaki $\mathrm{H}$ : Inhibition of nuclear factor kappaB and phosphatidylinositol 3-kinase/Akt is essential for massive hepatocyte apoptosis induced by tumor necrosis factor alpha in mice. Liver Int 2003, 23(5):386-396.

37. Chiao PJ, Na R, Niu J, Sclabas GM, Dong Q, Curley SA: Role of Rel/ NF-kappaB transcription factors in apoptosis of human hepatocellular carcinoma cells. Cancer 2002, 95(8): 1696-I705.

38. Babic AM, Chen CC, Lau LF: Fisp I/mouse connective tissue growth factor mediates endothelial cell adhesion and migration through integrin alphavbeta3, promotes endothelial cell survival, and induces angiogenesis in vivo. Mol Cell Biol 1999 , 19(4):2958-2966.

39. Gygi D, Zumstein P, Grossenbacher D, Altwegg L, Luscher TF Gehring $\mathrm{H}$ : Human connective tissue growth factor expressed in Escherichia coli is a non-mitogenic inhibitor of apoptosis. Biochem Biophys Res Commun 2003, 3 I I (3):685-690.

40. Lin MT, Chang CC, Chen ST, Chang HL, Su JL, Chau YP, Kuo ML Cyr6 I expression confers resistance to apoptosis in breast cancer MCF-7 cells by a mechanism of NF-kappaB-dependent XIAP up-regulation. J Biol Chem 2004, 279(23):240I5-24023.

4I. Lau LF, Lam SC: The CCN family of angiogenic regulators: the integrin connection. Exp Cell Res 1999, 248(I):44-57.

42. Cheresh DA, Spiro RC: Biosynthetic and functional properties of an Arg-Gly-Asp-directed receptor involved in human melanoma cell attachment to vitronectin, fibrinogen, and von Willebrand factor. J Biol Chem I987, 262(36): I7703-I77II.

43. Cheresh DA, Pytela R, Pierschbacher MD, Klier FG, Ruoslahti E, Reisfeld RA: An Arg-Gly-Asp-directed receptor on the surface of human melanoma cells exists in an divalent cation-dependent functional complex with the disialoganglioside GD2. J Cell Biol 1987, I05(3): II63-II73.

44. Gladson CL, Cheresh DA: Glioblastoma expression of vitronectin and the alpha $v$ beta 3 integrin. Adhesion mechanism for transformed glial cells. J Clin Invest I991, 88(6): 1924-1932.

45. Schwartz MA: Signaling by integrins: implications for tumorigenesis. Cancer Res 1993, 53(7): 1503-1506.

46. Brooks PC, Clark RA, Cheresh DA: Requirement of vascular integrin alpha $\mathbf{v}$ beta 3 for angiogenesis. Science 1994, 264(5I 58):569-57|.

47. Brooks PC, Montgomery AM, Rosenfeld M, Reisfeld RA, Hu T, Klier $G$, Cheresh DA: Integrin alpha $\mathbf{v}$ beta 3 antagonists promote tumor regression by inducing apoptosis of angiogenic blood vessels. Cell 1994, 79(7): | 157-1164.

48. Montgomery AM, Reisfeld RA, Cheresh DA: Integrin alpha v beta 3 rescues melanoma cells from apoptosis in three-dimensional dermal collagen. Proc Natl Acad Sci U S A 1994, 9l( 19):8856-8860

49. Drake Cl, Cheresh DA, Little CD: An antagonist of integrin alpha $v$ beta 3 prevents maturation of blood vessels during embryonic neovascularization. J Cell Sci 1995, 108 ( Pt 7):2655-266I.

50. Scatena M, Almeida M, Chaisson ML, Fausto N, Nicosia RF, Giachelli CM: NF-kappaB mediates alphavbeta3 integrin-induced endothelial cell survival. I Cell Biol I998, I4 I(4): 1083-1093.

5I. Miyauchi A, Alvarez J, Greenfield EM, Teti A, Grano M, Colucci S, Zambonin-Zallone A, Ross FP, Teitelbaum SL, Cheresh D, et al:: Recognition of osteopontin and related peptides by an alpha $v$ beta 3 integrin stimulates immediate cell signals in osteoclasts. I Biol Chem I99|, 266(30):20369-20374.

52. Iwamoto H, Sakai H, Tada S, Nakamuta M, Nawata H: Induction of apoptosis in rat hepatic stellate cells by disruption of integrin-mediated cell adhesion. J Lab Clin Med 1999, 134(I):83-89.

53. Reeves HLDCLDCPBAD: $\boldsymbol{B}$ I-integrin expression in hepatic stellate cells from normal and diseased human livers: 1997; Bordeaux, France,. Volume 6. Edited by: Wisse EKDLBC. The Kupffer Cell Foundation, Leiden, The Netherlands; 1997: I54-I55.

54. Richter HB, Franke H, Dargel R: Expression of tenascin, fibronectin, and laminin in rat liver fibrogenesis--a comparative immunohistochemical study with two models of liver injury. Exp Toxicol Pathol 1998, 50(4-6):3I5-322.

55. Carloni V, Romanelli RG, Pinzani M, Laffi G, Gentilini P: Expression and function of integrin receptors for collagen and laminin in cultured human hepatic stellate cells. Gastroenterology 1996 , I I0(4): I I 27-I I 36

56. Iwamoto $\mathrm{H}$, Sakai $\mathrm{H}$, Nawata $\mathrm{H}$ : Inhibition of integrin signaling with Arg-Gly-Asp motifs in rat hepatic stellate cells. J Hepatol 1998, 29(5):752-759.

57. Kato R, Kamiya S, Ueki M, Yajima H, Ishii T, Nakamura H, Katayama $T$, Fukai $F$ : The fibronectin-derived antiadhesive peptides suppress the myofibroblastic conversion of rat hepatic stellate cells. Exp Cell Res 200I, 265(I):54-63.

58. Trim N, Morgan S, Evans M, Issa R, Fine D, Afford S, Wilkins B, Iredale J: Hepatic stellate cells express the low affinity nerve growth factor receptor p75 and undergo apoptosis in response to nerve growth factor stimulation. Am J Pathol 2000, I56(4): | $235-1243$.

59. Wahab NA, Weston BS, Mason RM: Connective tissue growth factor CCN2 interacts with and activates the tyrosine kinase receptor TrkA. J Am Soc Nephrol 2005, 16(2):340-35I.

60. Hishikawa K, Nakaki T, Fujii T: Connective tissue growth factor induces apoptosis via caspase 3 in cultured human aortic smooth muscle cells. Eur J Pharmacol 2000, 392(I-2): 19-22.

6I. Hishikawa K, Oemar BS, Tanner FC, Nakaki T, Fujii T, Luscher TF: Overexpression of connective tissue growth factor gene induces apoptosis in human aortic smooth muscle cells. Circulation 1999, 100(20):2108-21 I2.

62. Hishikawa K, Oemar BS, Tanner FC, Nakaki T, Luscher TF, Fujii T: Connective tissue growth factor induces apoptosis in human breast cancer cell line MCF-7. I Biol Chem 1999, 274(52):3746I-37466

63. Friedman SL, Arthur MJ: Reversing Hepatic Fibrosis. Science \& Medicine 2002:194-205. 
64. Dignam JD, Lebovitz RM, Roeder RG: Accurate transcription initiation by RNA polymerase II in a soluble extract from isolated mammalian nuclei. Nucleic Acids Res 1983, II(5):1475-I489.

65. Pizzi M, Goffi F, Boroni F, Benarese M, Perkins SE, Liou HC, Spano P: Opposing roles for NF-kappa B/Rel factors p65 and c-Rel in the modulation of neuron survival elicited by glutamate and interleukin-I beta. J Biol Chem 2002, 277(23):20717-20723.

Publish with Biomed Central and every scientist can read your work free of charge

"BioMed Central will be the most significant development for disseminating the results of biomedical research in our lifetime. " Sir Paul Nurse, Cancer Research UK

Your research papers will be:

- available free of charge to the entire biomedical community

- peer reviewed and published immediately upon acceptance

- cited in PubMed and archived on PubMed Central

- yours - you keep the copyright

Submit your manuscript here:

http://www.biomedcentral.com/info/publishing_adv.asp 